\begin{tabular}{l|ll} 
DE & $\begin{array}{l}\text { DE GRUYTER } \\
\text { OPEN }\end{array}$ & ECONOMIC THEMES (2014) 52 (2): 197-214 \\
$\mathbf{G}$ & DOI $10.1515 /$ ethemes-2014-0014
\end{tabular}

\title{
THE IMPACT OF EXCHANGE RATE PASS-THROUGH ON SERBIAN EXPORT COMPETITIVENESS
}

\author{
Ivan Marković
}

University of Niš, Faculty of Economics, Serbia

\ivan.markovic@eknfak.ni.ac.rs

\section{Milan Marković}

PhD student; scholarship from the Ministry of Education, Science and Technological Development of the Republic of Serbia

$\bowtie$ markovicmilan89@gmail.com

UDC

336.784.12:

339.743

(497.11)

Review paper

Received:

24.01.2014

Accepted:

10.06.2014

\begin{abstract}
The permanent existence of inflation in Serbia adversely affects achievement of macroeconomic stability. Its effects are reflected in a decrease in the real exchange rate, low price competitiveness of exports and deterioration in the balance of payments. The real exchange rate is an instrument which shows that in conditions of faster growth rate in a country than abroad, the domestic economy can't be competitive in the international market. Implementation of appropriate exchange rate regime inevitably leads to problems of exchange rate changes on import prices and inflation. The research aims to demonstrate the interdependence of inflation and depreciation, and the fact that the general price level increase is a main factor that hinders the realization of the positive effects of the national currency depreciation. Unstable monetary situation in the country undermines the goal of stimulating exports through an increase in the nominal exchange rate and by reducing export prices in foreign currency. Export becomes uncompetitive, while the depreciation of the national currency is quickly spread to inflation through the exchange rate pass-through.
\end{abstract}

Keywords: inflation, real exchange rate, depreciation, competitiveness, exchange rate pass-through.

This paper is a part of a research project with reference number 179066, funded by the Ministry of Education, Science and Technological Development of the Republic of Serbia. 


\section{Introduction}

The global economic and financial crisis at the end of the first decade of the $21^{\text {st }}$ century, pointed out that despite the impact of the indoor environment on inflation, an important factor is the influences from the external environment. Therefore, in economic policy and science, knowledge of the exchange rate pass-through to prices is very important. Prices are presented as a general category, because it is known that theory considers the impact of exchange rate changes on import prices and general price level. The mechanism of exchange rate changes on import prices implies the study of relations between exchange rates and prices from the micro perspective, where impact of exchange rate on import prices transmitted by direct channels. On the other hand, the study of the exchange rate pass-through to inflation within the domain of macro analysis that includes both the direct and indirect transmission channels of exchange rate changes. The difference between the mechanism of exchange rate changes on import prices and inflation is especially important from the standpoint of the effect of diverting demand from imports to domestic products. Complete and rapid mechanism of exchange rate changes on prices of imported goods increases the effect of diverting demand from imports to domestic products, and more complete and rapid exchange rate pass-through to inflation reduces the effect of diverting demand from imports to domestic products (Miljković, 2008).

Inflation, the main problem of the Serbian economy, negatively affects many macroeconomic indicators. Among other things, the rise in the general price level prevents the action of the national currency depreciation (the growth of the exchange rate) to increase exports. In this case, the nominal exchange rate increases, but a rise in the inflation rate leads to decrease in the real exchange rate. Monetary instability affects not only the reduction of exports; the growth of the exchange rate (bearing in mind the theory of purchasing power parity) causes further price increases and this is called inflation - devaluation spiral. Exchange rate pass-through will be used in this research in order to comprehend the effects of exchange rate changes on inflation trends. We will analyze the direct and indirect channel through which depreciation is transferred to inflation. The exchange rate is a variable that largely determines the formation and movement of prices in Serbia. The inefficiency of the depreciation of the national currency indicates that the stable exchange rate is necessary to achieve macroeconomic stability, so the measures of exchange rate policy are very important. In order to curb inflation, the state implements the measures of prices control (measures of monetary, fiscal and international trade policy, competition policy). 


\section{The Relation between Inflation and the Depreciation of the National Currency}

Inflation and exchange rate are the macroeconomic indicators that are doubly linked. It can be argued that these variables are directly interrelated. Direct correlation implies that any increase in the general price level reflects on the growth of exchange rate, while the depreciation of the national currency in turn shall return to the implications of inflation. This is especially prevalent in developing countries which are inflation inertial. Figure 1 can graphically represent this correlation in Serbia. In addition, in the calculation of the inflation rate we used the annual increase in the price level (the general price level in December of the year compared with the same month a year earlier). A similar principle and the use of indices chain is applied to obtain the annual growth rate of the exchange rate (the data about the levels of exchange rates at year-end).

Figure 1 The Annual Rate of Increase in the General Price Level and the Exchange Rate

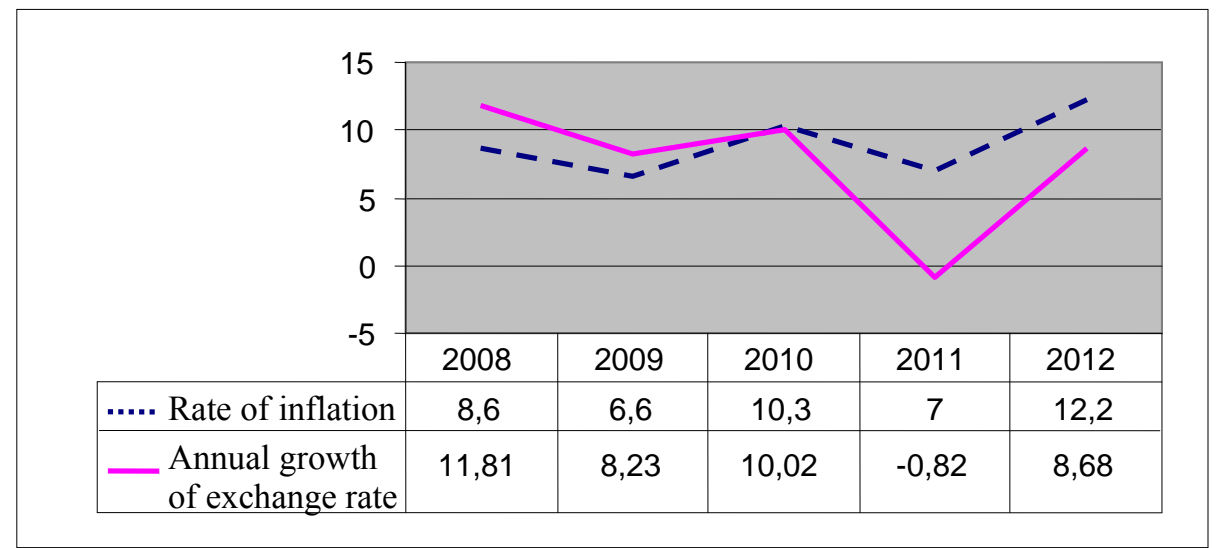

Source: Author's calculations based on data of the National Bank of Serbia, 2013

Thus, the exchange rate and inflation are in the correlation. In countries that are highly import-dependent (such as Serbia), this relationship is very much present, taking into account the psychological factors that enhance the relationship. It can be said that inflation is the cause, but the consequence of the depreciation of the national currency, too. In this regard, there is the term "inflation-devaluation spiral", which leads to the currency crises. Therefore, it is important to understand the relationship of these macroeconomic variables through the mechanisms of mutual influence, and their synergistic effects on the country's exports. Trade imbalance and psychological factors create a constant depreciation pressure, which leads to inflationary pressure due to the strong increase in the transmission of exchange rate on inflation (Janković and Stanisić, 2012, p .405). 


\subsection{Determinants of Inflationary Disturbances in Serbia}

Inflation, as a major economic phenomenon, is an increase in the general price level. As main macro-economic indicator, prevents the achievement of macroeconomic stability. Most economies are facing inflation, especially emerging economies. According to the underlying causes of its origin, we distinguish cost-push and demand-pull inflation. In the Republic of Serbia and other countries with undeveloped markets, dominate factors on the cost side (supply). It is the following determinants of the increase in the general price level: a monopolistic market structure, volatility of food market, increase of taxes (primarily indirect taxes), devaluation of the national currency.

Monopolistic and oligopoly situations are typical on the modern markets. In such market structures, seller can make decisions regardless of other participants and thus influencing the formation of higher prices of certain products. Limiting competition reduces the possibility of choice, leading to the practice of independent determination of prices by a monopolist. Bearing in mind that significant parts of national markets are markets of oil, sugar, milk, petroleum, more or less limited due to weak competition, increasing prices on these markets significantly affects the increase in the general price level. Thus, the inflationary effects of oligopoly can be expressed if this market conditions are present in the production and distribution of basic goods (which account for a large share of the consumer price index). Serbia, according to the lists of the World Economic Forum, is a country with great influence of monopolies and cartels, which is the main reason for the continuous exercise of the highest inflation rates in the region.

In the analysis of food markets, we can see that the imbalance between supply and demand often occurs. The mismatch usually occurs due to reduced supply, so the specific characteristics and trends on this market are important in considering the fundamental determinants of inflation. It is about the following facts which indicate that the stability of food markets is necessary for the preservation of a stable rate of inflation:

- In contrast to the demand for primary agricultural and food products, which is the primary, mass and prompt, their offer vary due to many factors of formation in food prices,

- The share of food in the consumer price index is $34.5 \%$, so this product group has a dominant influence on inflation and

- Prices of food products are significantly more volatile than the movement of prices of non-food products.

The increase in the absolute amount of tax, due to an increase in the tax rate or expanding the tax base, has an inflationary effect. In this case producers are discouraged, which leads to a reduction in supply of goods in the market. It 
should be noted that indirect taxes have significant inflationary potential, because finally it is paid by the final consumers through the mechanism of shifting. Typical examples are the value-added taxes and increase of excises.

In Serbia, as a country with high inflation expectations and the existence of vast import dependence due to the lack of domestic substitutes, the increase of the exchange rate quickly spread to inflation. This will be analyzed in consideration of the exchange rate pass-through to inflation.

\subsection{The Exchange Rate as a Factor of Price Competitiveness on Foreign Markets}

The growth of the exchange rate (decrease in the value of the national currency) is a way to stimulate exports through price competitiveness of domestic products in the foreign market. This is because the increase in the nominal exchange rate lowers the price of exports denominated in foreign currency. This encourages exporters, which can increase competitiveness by reducing the prices of its products on foreign markets. It should be noted that the price is the dominant factor of competitiveness in the crisis.

Theoretically, the devaluation of the national currency ${ }^{2}$ stimulates exports, reduces imports, thereby reducing the current account deficit and encourage domestic production (Nikolić, 2010). However, the results of previously legality in Serbia are not achieved, and the factors that make it impossible will be analyzed below. Unlike our and other less developed countries, the exchange rate as an instrument to encourage exports is used by developed economies, in which there exist the conditions that underrated national currency stimulates exports, and hence domestic production, bearing in mind the cost reduction per unit of production. The main factor that prevents the positive effect of reducing the value of the national currency is an unstable monetary situation (Acin et al., 2006).

A useful tool for understanding the (price) competitiveness of domestic products on foreign markets is the real exchange rate. The real exchange rate is based on the nominal exchange rate which is "cleaned" by the impact of inflation. It can be expressed using the following formula:

$$
e=\frac{E^{*} P^{*}}{P}
$$

\footnotetext{
${ }^{2}$ Reducing the value of a currency in a fixed exchange rate system is called devaluation, while in the floating exchange rate in the same case, there is depreciation. Bearing in mind that they are many modalities between this exchange rate regimes (which are extremes), the literature frequently makes no difference in this terminology.
} 
Where:

$e$ - the real exchange rate,

$E$ - the nominal exchange rate,

$P$ - the general price level in the country and

$P^{*}$ - the general level of prices abroad.

The consumer price index is commonly used as an indicator of the general price level in the country. Directly from the form itself it can be concluded that the increase in inflation in the domestic economy, or more specifically, the rapid growth of domestic than foreign price (assuming the constancy of the nominal exchange rate) leads to a decrease in the real exchange rate, i.e. its appreciation. In these conditions, exhibit a decrease in the price competitiveness of domestic products that are exported. The deficit of trade balance just shows that Serbian export (and thus the economy) is uncompetitive.

Many factors affect the real exchange rate (Miljković, 2008). One of them is the change in the value of aggregate output (gross domestic product). When there is a tendency of decrease in the aggregate supply of goods in the market, this implies a price increase. In such situation, based on the form to calculate the real exchange rate, there is a decrease, i.e. appreciation of the real exchange rate and reduction of the competitiveness of the domestic economy. All this causes a reduction in export revenues and the possibility of deterioration in the balance of payments. Otherwise, the inflow of foreign exchange from exports of goods and services is "healthy" gain and it is the basic determinant of the balance of payments adjustment. The next factor is the growth of inflation and inflation expectations. As we have already concluded, the growth rate causes decrease in the real exchange rate and consequently, decrease in the competitiveness of exports. However, significant inflation expectations can, through increase nominal interest rates, decrease the nominal exchange rate, which will in turn enhance the effect of the appreciation of the real exchange rate. Due to continuing effects of inflation, domestic exporters on foreign markets can't be cost-competitive (without considering the possibility of non-price aspects of competitiveness). Overvalued national currency, as well as higher interest rates and taxes in the country than abroad, and the best economy will make it uncompetitive on the international market (Kovač, 2006).

Competitiveness analysis often relies on the difference between pricing and structural competitiveness. Structural competitiveness is usually defined as all those factors that aren't included in the price. These include specialization in economics, technology innovation, and quality of the distribution network and a host of other factors that basically make the environment in which a single company operates. Factors that determined the structural competitiveness of the country are reflected in the overall efficiency of the national economy, the ability to adapt the structure of its industry to the new changes, the rate and manner of use of capital investments, as well as the technical infrastructure. 
Any change in the structural character will affect the competitiveness of firms, given the interactive relationship between the environment and the company's operations.

There is no doubt that both forms of competition are significant, but the pricing, or the cost dimension is easier to measure, and in particularly it is often the center of discussion, because it will have lower costs and be costcompetitive, has a direct impact on the macroeconomic factors as well as changes of exchange rate. Certainly, small exchange rate changes inevitably will affect the unit costs of labor, so that for example devaluation of the national currency will reduce the real wage to the level at which the work of the country that made the devaluation, really worth, and contribute to a reduction in unit labor costs. This will result in an increase in price competitiveness, but also certain social problems resulting from lowering wages. The opposite situation will occur in the case of a revaluation of the national currency.

By definition, any measurement of the cost competitiveness is relative, by linking the costs and rates of any sector of the economy, or to compare costs and rates of any sector of a national economy, with prices and costs in the same sectors in other countries. If the ratio of changes in the cost and price is a little over time, the cost-competitive will be moved in parallel with the movement of price competitiveness. That will not happen, for example, if manufacturers reduce profit margins in response to the depreciation of the national currency, and thus maintain the relative price competitiveness.

The difference must however be underlined with respect to an absolute indicator of cost difference, whereby must take into account the time component, in terms of comparing costs and prices over time. Many empirical studies and measurement of cost competitiveness have focused only on the trends and changes in relative costs, while not allowing absolute comparisons. This is the core issue and problem that arises in measurement of the competitiveness: a lack of adequate relative prices that would turn, and have reduced the productivity of the industry to a common denominator. Using the exchange rate, costs and consumption expands the concept of purchasing power parity, while still in its original size may not reflect differences in industrial production. Recognizing these difficulties, the indicators are therefore deliberately focused to show the relative changes in cost competitiveness (Marković and Janković - Milić, 2013).

It can be said that homogeneity of the growing weight products is lost today, and all products have not the same importance to the customer, which is why he/she chooses one of these products foregrounding their own system of evaluation and favoritism. Over time, the system of evaluation of the consumer has changed, and therefore the decision of the factors of the purchase. It is known that in the period of mass production (the sixties), due to high demand 
and high production costs, the price was the determining factor of competitiveness. However, where the purchasing power is small, where customers cannot afford to buy luxury products, the price is still the leading factor of competitiveness. In addition to cost, there are other factors that affect on the competitiveness of products which are classified in the non-price factors of competitiveness. This group of factors transformed the global market from "price market" to "quality market". However, although these factors are defined as non-price, they still have their price. But what is visible to the customer is the price that may be higher or lower to products that may or may not meet the buyer in full. Although a large number of non-price factors that determine the competitiveness of the product exist today, must not be lost sight of, and totally ignoring price as a factor, because there is a very large number of countries that belong to the undeveloped and whose total population accounts take a huge part of the world's population, where the price is the determining factor of competitiveness. In support of the above mentioned is the fact that 4 billion people on the planet has a very modest standard of living. Also, some elements of the price are still very important for the purchase of certain products. Sustainable growth in exports now can be realized only through the creation of the above-mentioned conditions. Although prices have less importance in explaining competitiveness in contrast to earlier periods, prices are still an important factor for standardized products and for countries with low income per capita (Jefferson Institute, 2003).

In order to increase competitiveness at the national level, it is necessary to create a stable environment, to invest in education and implement the Law of Competition Protection. Policy makers may intervene through exchange rate policy and subsidies, which would play the role of auxiliary instruments.

\subsection{The Consequences of an Increase in the General Price Level on the Exchange Rate}

One of the main determinants for the exchange rate determination is the price level. If we accept the law of one price and purchasing power parity, which is the basis of it done, it can be concluded that the increase in the price level is a cause of the depreciation of the national currency. Purchasing power parity can be expressed in the form of absolute and relative theory. Absolute purchasing power parity assumes that the exchange rate is the ratio between the price level in the country and abroad. This is shown by the following formula: 


$$
E=\frac{\sum_{i=0}^{n} \alpha_{i} P_{i}}{\sum_{i=0}^{n} \alpha_{i} P_{i}^{*}}
$$

Where:

$E$ - the level of the exchange rate,

$P$ - the general price level in the country,

$P^{*}$ - the general price level abroad and

$\alpha$ - ponders (participation of individual product prices in the general price level).

In the assumption that ponders are the same between countries, we conclude that the increase in the general price level in the country, with other unchanged variables, raises the exchange rate. It is mathematically shown from the formula, but the same attitude can come by economic way of thinking. Increasing domestic prices discourages producers to export. They may sell their products at higher prices in the domestic market and earn higher income. From the point of import, importers will not buy raw materials and finished goods in the country, because they can be provided from abroad at lower prices. All of this affects the growth of demand for foreign currency, decline in inflow of foreign currency (due to lower exports) and, consequently, on the depreciation of the national currency. In contrast to the absolute theory, relative theory says that an increase in the exchange rate reached only if the growth rate of domestic products is higher than the increase in prices of products abroad. Therefore, the dinar depreciated against the euro due to the higher rate of increase in the general price level in Serbia in relation to the euro area over the same time period. It is the so-called "inflationary differential" (Jefferson Institute, 2003). Inflation leads to real appreciation of the exchange rate, although the nominal exchange rate rises.

The distinction between short and long term is important in considering the effects of inflation on the exchange rate. In the short term, it allows the possibility that the increase in the price level leads to a drop in the exchange rate. The increase in inflation rate increases the nominal interest rate (which is made up of real interest rate and inflation rate, bearing in mind the so-called Fisher effect). This causes a capital inflow, so as a result of increased foreign exchange supply is a decline in the exchange rate. It is the so-called theory of uncovered interest rate parity, where the movement of capital plays a dominant role (Miljković, 2008). In the long term, in the case of rising prices, the depreciation of the national currency is inevitable. In this case, inflation, i.e., increase in prices of goods and services in the conditions of purchasing power parity, will permanently increase the exchange rate. In countries that are highly 
import-dependent where there are high inflationary trends and expectations, the growth of the exchange rate will have an effect on the price increase and so will create a vicious circle from which there is often no way out if the state don't take adequate the measures of monetary and exchange rate policies.

\section{Exchange Rate Pass-Through to Inflation}

Transmission mechanism of the exchange rate (exchange rate pass-through) is used to show the effects of exchange rate changes on inflation. It is viewed how units change in the exchange rate affect on the change in the general price level. The depreciation of the national currency increases the price of imported products, and increases prices of domestic products due to price increases of imported inputs. If the rise in the exchange rate affects more the growth of import prices, the initial goal of economic policy will be realized - diverting demand from imports to domestic products. Otherwise, fast and complete mechanism of exchange rate changes on inflation reduces the effect of diverting demand from imports to domestic products (Miljković, 2003). Inflation and import will be increased, as well as a further increase of the exchange rate. The output from this vicious circle won't be possible, especially in economies where is a high dependence on imports and inflation expectations. Because of this, policy makers should be aware of the mechanism of action of the exchange rate on inflation. The mechanism can be explained through direct and indirect channel. Thereby, the direct channel is characteristic for the less-developed countries, and the indirect channel is present in the developed countries. Figure 2 shows the mechanism of the exchange rate on consumer prices.

Direct channel implies that an increase in the exchange rate increases the costs of imported raw materials (due to rising import prices in domestic currency), which are used in the production of local products. This is a typical example of cost-push inflation, when the costs of production increase prices of final products. On the other hand, when state imports finished products, the growth of import prices of these products is directly transmitted to inflation. In the first case it is the secondary (indirect), and in the second is the primary effect of currency depreciation. The effect of an increase in the exchange rate on the increase in domestic prices expressed in the rate of import dependency ratio (the ratio of imports to gross domestic product), which is multiplied by the rate of devaluation (Ćirović, 2000, p. 357). All this is typical for economy that doesn't have domestic substitutes, which is highly import-dependent, and in which consumer price index imported products is a significant component. A typical example relates to energy imports (mainly oil and oil products) where there is a low elasticity of domestic demand for imports. Also, most of the imported goods can't be substituted by domestic consumption in the country where there is no adequate production capacity or technology for a given production. If this were not the case, more expensive imports could be replaced by domestic products. 
Figure 2 Exchange Rate Pass-Through to Inflation

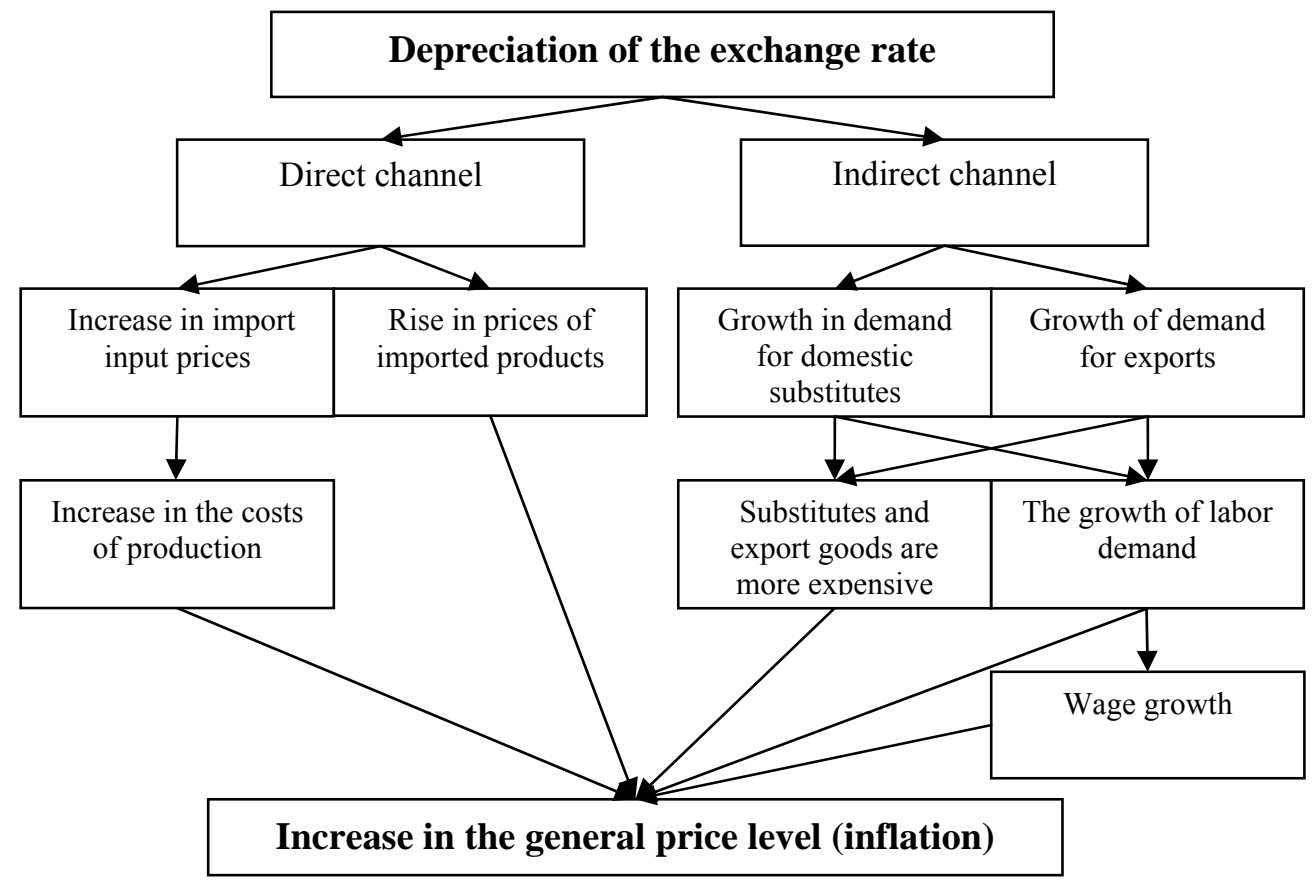

Indirect channel implies that the depreciation of the local currency and the rise in prices of imported products raises demand for domestic substitutes. Taking into account demand-pull inflation, this could be immediately reflected in the general price level, and from the standpoint of cost inflation due to increased demand of labor, the effects of an increase in wages remitted to the growth of consumer goods prices. On the other hand, due to the reduction in export prices expressed in foreign currency, and due to the growth of the exchange rate, exports of domestic products will increase. In this case there is a lack of goods on the domestic market, domestic products are more expensive and pressures on inflation occur again.

Depreciation of the national currency affects the growth of exports and reduces imports. This implicates reducing the price of exports denominated in foreign currencies, which stimulates exporters, and on the other hand there is an increase of import prices in domestic currency, which in turn, discourages imports.

As for the less developed countries (such as Serbia), positive effects of depreciation is not manifested in an increase in exports and decrease in balance of payments deficit, i.e. improvement in the balance of payments. Even after the depreciation of the national currency, imports can decrease. This is because our country does not have domestic substitutes (for example goods from electronics, 
computer technology and other industrial products, energy). Although there is an increase in import prices in domestic currency, due to the low elasticity of domestic import demand, import volumes will not be significantly reduced, i.e., maybe there will be an increase in the value of imports ${ }^{3}$. This can be seen in the example of oil and petroleum products involved in food production, service provision, but also in the other segments of consumer basket. Not only that there is a deterioration in the balance of payments, but under such conditions that increases the cost of imported inputs, there is a rise in production costs, which directly leads to the growth of consumer prices (cost-push inflation). Thus, developing countries are highly import-dependent, so the more expensive imports affect the prices of imported consumer products. And in terms of exports, there are no positive effects due to the lack of competitiveness of Serbian exports, the effect of inflation and the low degree of elasticity of foreign demand for domestic exports. The only positive factor is that the national currency depreciation reduces real wages and pensions (income denominated in euros), which in turn leads to a reduction in aggregate domestic demand and imports (due to a huge number of imported products) (Todorović and Velicković, 2010, p. 268).

Monopolization of the market is a factor explaining the situation that the decline in the exchange rate (appreciation of the national currency) does not cut prices in the country, although it reduces the price of imports in domestic currency. Monopolies prevent "price flexibility down". This benefit is useful only for "import lobby", i.e. large monopolies in the import sector. Therefore, it is concluded that in such circumstances, an increase in the exchange rate will not be much impact on improving the balance of payments, while the decline in the exchange rate will not reduce prices of imported products because of the action of monopolies and oligopolies, downward price rigidities and inflation inertia.

On the other hand, Serbia has a low domestic supply of exports and insufficient stocks of products for export which would immediately be ready to offer foreign buyers. The structure of exports from the standpoint of this analysis is unfavorable, in the sense that a significant portion of exports are agricultural products (about $25 \%$ ).Taking into account the specifics of this production (the dependence on natural factors, the long production cycle, the lack of a system of public storage, improper functioning of stockpiles, etc.), it is clear that one cannot in the short term respond to favorable market conditions, on the increase in domestic demand, or on the increase in foreign demand for

\footnotetext{
${ }^{3}$ The value of imports in domestic currency is obtained as follows: the quantity to be imported * import prices in foreign currency * exchange rate. Slight decrease in imports along with the increase of exchange rate can lead to an even greater deficit in the current account. The low elasticity of imports in domestic demand (low sensitivity of demand for imports to rise in the exchange rate) is the result of high import dependence of the Serbian economy.
} 
domestic products. Offer is inelastic in the short term, and determined by existing state of the stock. Second problem is a large number (quantity) of import inputs. The depreciation, i.e. increase in prices of imports, automatically leads to an increase in the prices of final goods. The high level of imports causes an increased sensitivity in the sense of imported inflation. The increase in prices abroad very easily can be transferred to the importing country. A typical example is the increase in prices of petroleum and petroleum products, which are our major import products (raw materials) that are used as inputs in the production. Whenever there is an increase in the exchange rate, almost all of the products are more expensive because of rising energy prices. This is all because domestic demand for imports is inelastic on price increases of foreign products.

\subsection{Monetary Stability: A Prerequisite for the Realization of the Positive Effects of Depreciation on the Export Competitiveness}

Depreciation of the national currency, in view of the previous analysis, will not have effects on exports increase because inflation will "eat" the devaluation. Specifically, in terms of the growth of the exchange rate in the long term, prices must be higher (in both developed and less developed countries). Inflation prevents improving the balance of payments through an increase in exports and decrease imports, through the depreciation of the national currency. Exporters, in these circumstances, which are related to the growth of domestic prices, will not be encouraged to export because good incomes they can be achieved by selling products in the domestic market. So, in the terms of unstable monetary situation, it is a difficult to provide the positive effects of an increase in the exchange rate. That is why it is said that a successful devaluation requires the simultaneous application of restrictive fiscal and monetary policies. In order to prevent the negative effects of depreciation on inflation, state often undertakes import liberalization.

Moderate inflation has been characteristic for Serbia in the last decade, while due to hyperinflation nineties, there are high inflation expectations. Psychological factors can be significant barriers to the successful conduct of economic policy and the manifestation of the positive effects of indirect price control measures taken by the state in preventing inflationary tendencies.

Inflation is a "disease of the economic body". The goal of policy makers is to completely eliminate this macroeconomic disorder. The increase in the general price level occurs whenever the market of a product is shortage of supply with constant demand or excess demand at a constant offer. Therefore, public authorities made various programs to balance supply and demand and stop the uncontrolled growth of prices. Taking measures to increase or decrease 
the supply and demand, the state indirectly affects on the level of prices of goods and services in the market (Božić, 2009, p.131).

One of the reasons for the increase in the general price level is reflected in the exercise of monopoly (and oligopoly). They aspire to achieve the high rates of profits through price increases. Therefore, it is necessary to provide adequate public policies toward monopoly. The aim of competition policy is to prevent the dictation of prices by a monopolist or a dominant influence in countries with underdeveloped markets. Reducing commodity funds (for example, due to natural disasters, bottlenecks in production, shortages of agricultural products used in the food industry) causes a deficit on the goods market. Emergency imports, export ban, adequate function of stockpiles and storage policies, have a crucial role in stabilizing the market of certain products. Account deficit has been typical for our country in the last decade. Growth in imports means increasing demand for foreign exchange. This raises the exchange rate, which ultimately leads to rise in prices of goods. Taxes affect inflationary and on the other hand, disinflationary. Taxes can be seen as factors on the supply side (the tax increase), and a major determinant of demand-pull inflation (tax cuts). Tax cuts can be encouraging for the company, but an increase in aggregate demand can be demonstrated effects on inflation. Making decisions on the amount of tax is very complex question, since it is obvious that changing the level of taxation does not produce unique results. They have different effects on the price level, and the creators have to well analyze and predict their final (net) outcomes. In Serbia, tax increases mainly discourage entrepreneurs and the supply of goods is lower. By reducing the tax burden we expect positive impact of tax increase on companies' production, and thus, lowering prices. Producers then are encouraged to increase investment and production. When is dominant cost element, then the tax cuts may have anti-inflationary effect, provided that the follow-up and additional measures of economic policy absorb the increased purchasing power of taxpayers, due to an increase in real disposable income. All this would be ideal if the economy had no problems with high budget deficits and public debt that require an increasing amount of the tax burden to finance them.

The increase in aggregate demand (absorption) due to an increase in personal, investment and public spending is one of the factors on the demand side. Public (government) spending increase is a key cause of the growth of prices. It will not cause inflation only when it is in proportion to the growth of national income. Investment spending is the least problematic, because it is essential to reduce unemployment and eliminate stagnation in process of economic growth and development. Investments may temporarily cause inflation. But a bigger problem may be bad investments. The effects of restrictive monetary policies are reducing investment spending, the liquidity of the economy, etc. Anti-inflation policy is implemented through a restrictive monetary policy and aims to cool the "overheated" economy. By increasing the benchmark interest rate, the rate of 
required reserves and sales of securities, central bank reduces aggregate demand, through the reduction of the money supply.

Besides ensuring price stability in the long term, it is important to prevent fluctuations in exchange rates by purchasing and selling of foreign currency. One-time foreign exchange rate movement in any direction can produce macroeconomic instability. For defense of the exchange rate there are sufficient foreign exchange reserves, which are more than optimal. The best level of foreign exchange reserves is one that covers the quarterly import and does not exceed the level which provides covering six months of imports. Significant value of foreign exchange reserves is not good, because the increase in the money supply affects the growth of prices. On the other hand, they are not an endless source of financing the balance of payments imbalances. Reduction below the previously defined optimal level will impact on reducing the country's credit rating, preventing borrowing on international capital markets and this may also creates inflation. Lack of reserves encourages inflation because of short-term capital outflows which leads to the depreciation of the national currency, and destabilizes internal balance in accordance with the exchange rate pass-through to inflation.

Serbia is a country characterized by a high degree of correlation between inflation and the exchange rate, because the economy is highly dependent on imports. Thus, there is a high degree of flexibility, so that exchange rate changes quickly reflected on the prices. Since inflation has a reverse influence on the exchange rate, the key to success is to maintain the stability of the exchange rate and the general price level. The high inflation rate becomes unrealistic, so that the economy cannot be competitive in exports. Therefore, the economic policies in combating inflationary disorder is very important, because it indirectly affects the stability of the exchange rate and the overall macroeconomic situation.

One of the main challenges for monetary authorities is to assess the impact of shocks related to the movement of exchange rates and import prices to domestic prices (Tasić, 2008). Bearing in mind that the National Bank of Serbia implements inflation targeting strategy and that Serbia belongs to the group of small open economies, the exchange rate is very sensitive to the flow of foreign capital. Shocks which related to changes in exchange rates are often the main constraint for achieving the planned rate of inflation. The inflation sensitivity and an increase in the exchange rate are typical problems affecting the impossibility of achieving the primary objective of monetary policy - price stability. Numerous empirical studies have shown that the stronger effect of exchange rate changes on prices is in the less developed economies (mostly import-dependent). 
In Serbia, the managed floating exchange rate is implemented. The given exchange rate regime implies that the value of foreign currencies freely formed in the foreign exchange market (through the relationship of supply and demand for foreign exchange), while the central bank intervenes to prevent excessive daily volatilities of the exchange rate. Exchange rate stability is essential in achieving stability of prices and overall macroeconomic stability. A stable exchange rate is suitable for all businesses, because the depreciation or appreciation of the national currency in Serbia will not give positive results. Not only is such a course desired by importers and exporters, but also the citizens want a stable exchange rate, because it keeps real wages at a relatively stable level. Therefore, it is logical to conclude that the stability of the national currency is a key for economic stability, increasing predictability and reducing an uncertainty.

The choice of exchange rate regime and exchange rate policies are the key factors that affect on all of the criteria of macroeconomic efficiency of the economy. It also solves many of inflation and foreign trade issues. Exchange rate policy is a very important element of economic policy. Due to problems with inflation, many economists recommend a fixed exchange rate regime or some of its modalities. However, there are several reasons why this is not the optimal strategy for Serbia, at least not with such characteristics of the Serbian economy, because, as concluded Frankel (1999) there is no single exchange rate regime, which can be applied at any time. These are the following facts:

- Fixing the exchange rate in the short term reduces inflation, provides the stability and confidence in the conduct of monetary policy. But in the long run, due to the presence of inflationary expectations and sensitivity, there is a reemergence of inflation. This leads to a devaluation-inflation spiral. In this case, the real exchange rate is being reduced, the economy loses competitiveness, there is the problem of balance of payments deficit and the possibility of a currency crisis because of reducing foreign exchange reserves due to finance balance of payments deficit,

- Structural characteristics of the economy (low labor mobility and a low level of production and export diversification) prevent realizing the benefits of a fixed exchange rate. However, in recent months, Serbia has increased diversification of exports, in addition to primary agricultural products, our country intensify exports of cars and petroleum products,

- A significant disadvantage of this mode is the loss of independence of monetary policy (monetary authorities cannot change the exchange rate to stimulate exports and improve the balance of payments). A few years back Serbia has a deficit of foreign trade with other countries. Exchange rate flexibility should be the absorber adjustment to external shocks, which is the main advantage of a floating exchange rate regime. We will clarify this fact. Growth in imports means an increase in demand for foreign currency 
(due to imports which is paid by foreign currency). This, according to basic market principles, imply raise of the exchange rate. In the case of the fulfillment of stability conditions in the foreign exchange market (the conditions of the Marshall - Lerner theorem), the growth of the exchange rate causes an increase in the value of exports and provides favorable balance of payments. It wouldn't be possible in the fixed exchange rate regime.

\section{Conclusion}

Inflation is a phenomenon that negatively affects almost all aspects of social and economic life. A wide range of factors have an impact on the general price level in Serbia. On the other side, underdeveloped markets, factors on supplyside, which influence cost inflation, are dominant. Encouraging exports by reducing the value of the dinar in the present circumstances of high inflation rates and other characteristics of the Serbian economy (low competitiveness of products, small domestic supply for exports) is simply impossible. In the conditions of high import dependence, the existence inflation sensitivity and monopolization of the market, the only effect of an increase in the exchange rate is reflected in further price increases. This means that in the Republic of Serbia the relation: inflation - exchange rate - inflation is unbreakable. Many economic models have shown that if inflation expectations are great, the impact of exchange rate changes on inflation is greater.

The increase in the exchange rate will not be a means to increase exports until the economy faces with a high rate of inflation. Hence, the measures and instruments of price regulation, particularly measures of monetary and exchange rate policies are very important. Therefore, it is important that policy makers propose a set of measures to achieve monetary stability. Appropriate and simultaneous actions of the government and the central bank are used in a scope of stabilizing measures in controlling inflation. The central bank has to maintain exchange rate stability, because its change in any direction will not affect the initial goals of the economic policy in the Serbian economy.

\section{References}

Acin, Đ., Todorović, M. \& Acin-Sigulinski, S. (2006) Međunarodni ekonomski odnosi, Novi Sad: Pigmalion.

Božić, M. (2009) Ekonomska politika, Niš: Pravni fakultet - Centar za publikacije.

Frankel, A. J. (1999) "No single currency regime is right for all countries or at all times", NBER Working paper, No 7338, National Bureau of Economic Research, Cambridge, MA 02138, September. 
Janković, N. \& Stanišić, N. (2012) "Problem izbora adekvatnog režima deviznog kursa u Srbiji", Ekonomske teme, 50 (3): 391-414.

Jefferson Institute (2003) "Konkurentnost privrede Srbije", Beograd: Džeferson institut.

Kovač, O. (2006) "Konkurentnost i politika deviznog kursa u Srbiji", Megatrend revija, 3 (1): $5-18$

Marković, I. \& Janković-Milić, V. (2013) "Konkurentnost u novim uslovima poslovanja", Strategijski menadžment $i$ sistemi podrške odlučivanju u strategijskom menadžmentu, Korporativno upravljanje u funkciji održivog razvoja, Subotica: Ekonomski fakultet, pp. 684-689.

Miljković, D. (2003) "Mehanizam uticaja promene deviznog kursa na inflaciju", Ekonomski anali, 48 (3): 149-167.

Miljković, D. (2008) Međunarodne finansije, Beograd: Ekonomski fakultet.

Narodna banka Srbije (2013) “Izveštaj o inflaciji - maj 2013”, Beograd: NBS.

Nikolić, G. (2010) "Uticaj depresijacije deviznog kursa i berzanskih tendencija na konkurentnost", Škola biznisa, 7 (1): 102-109.

Tasić, N. (2008) „Pass-through deviznog kursa na cene u Srbiji: 2001- 2007”, NBS Radni papiri, No 10, Narodna banka Srbije, Beograd, februar.

Todorović, M. \& Veličković, M. (2010) "The impact of exchange rate depreciation on business conditions in Serbia", Facta universitatis, 7 (3): 263- 270.

Ćirović, M. (2000) Devizni kursevi, Beograd: Bridge company.

\section{THE IMPACT OF EXCHANGE RATE PASS-THROUGH ON SERBIAN EXPORT COMPETITIVENESS}

Apstrakt: Permanentno postojanje inflacije u Srbiji negativno utiče na ostvarenje makroekonomske stabilnosti. Njene posledice ogledaju se u smanjenju realnog deviznog kursa, niskoj cenovnoj konkurentnosti izvoza i pogoršanju stanja u platnom bilansu. Realni devizni kurs predstavlja instrument koji pokazuje da u uslovima bržeg rasta cena $\mathrm{u}$ zemlji, nego $\mathrm{u}$ inostranstvu, domaća privreda ne može biti konkurentna na inostranom tržištu. Implementacija adekvatnog režima deviznog kursa neminovno dovodi do problema mehanizma uticaja promene deviznog kursa na uvozne cene i inflaciju. Istraživanje ima za cilj da pokaže međuzavisnost inflacije i depresijacije, kao i to da je rast opšteg nivoa cena glavni faktor koji ometa realizaciju pozitivnih efekata depresijacije nacionalne valute. Nestabilna monetarna situacija u zemlji narušava cilj stimulisanja izvoza putem porasta nominalnog deviznog kursa, a preko smanjenja cene izvoza u stranoj valuti. Izvoz postaje cenovno nekonkurentan, dok se depresijacija nacionalne valute brzo prenosi na inflaciju preko transmisionog mehanizma deviznog kursa.

Ključne reči: inflacija, realni devizni kurs, depresijacija, konkurentnost, transmisioni mehanizam deviznog kursa. 